\title{
Regulation of Axonal Caliber, Neurofilament Content, and Nuclear Localization in Mature Sensory Neurons by Nerve Growth Factor
}

\author{
Bruce G. Gold, ${ }^{1}$ William C. Mobley, ${ }^{2}$ and Stephen F. Matheson ${ }^{3, a}$ \\ ${ }^{1}$ Center for Research on Occupational and Environmental Toxicology, The Oregon Health Sciences University, Portland, \\ Oregon 97201, 'Department of Neurology and Pediatrics and the Neuroscience Program, University of California, School

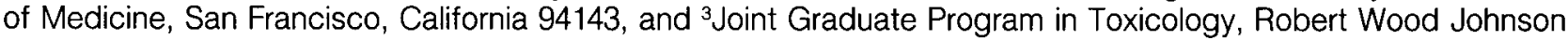 \\ University School of Medicine and Rutgers University College of Pharmacy, Piscataway, New Jersey 08854
}

The neuronal perikaryal response to axonal injury (axon reaction) includes reduction in axonal caliber beginning in the proximal portion of the nerve (somatofugal axonal atrophy), development of nuclear eccentricity, and chromatolysis. The means by which these events are triggered is unknown, but it has been argued that loss of a neurotrophic signal from the target of injured neurons plays a role. To date, the identity of this substance(s) remains unknown. In the present study, we have asked whether NGF normally functions to control axonal caliber of sensory neurons in the L4 and L5 dorsal root ganglia (DRG) of the adult rat. Two approaches were used: (1) NGF was continuously delivered to the proximal stump of a transected sciatic nerve to determine whether NGF administration would prevent the production of somatofugal axonal atrophy; and (2) NGF antisera were administered to normal animals to determine whether NGF deprivation would produce somatofugal axonal atrophy.

In the first experiment, 9-week-old rats underwent a unilateral sciatic nerve transection at midthigh, and the proximal stump was connected to an osmotic pump containing either NGF or cytochrome C (as control). At 11 weeks of age, dorsal root fibers in lumbar DRG from the control group appeared smaller in caliber and less circular in shape than fibers from age-matched normal animals. Although smaller than those in normal animals, fibers from the NGF-treated nerves were larger than in axotomized controls. Mean axonal area and shape factor (an index in circularity) were measured and found to be decreased significantly $(22 \%$ and $15 \%$, respectively) from the control group. Fibers from the NGFtreated nerves were significantly $(p<0.05)$ larger in axonal caliber and more circular in shape; mean values were only reduced by $11 \%$ and $10 \%$, respectively. Quantitation of neurofilament (NF) numbers revealed that the larger calibers in the NGF-treated nerves result from a greater NF content.

\footnotetext{
Received Apr. 12, 1990; revised Nov. 14, 1990; accepted Nov. 16, 1990.

We thank Dr. Valerie Verge for manuscripts made available prior to publication, Ms. Nancy Watkins and Mr. Michael deBoisblanc for technical support on the Western blots and in vitro bioassays, Dr. Robert Kayton and Mr. Dan Austin for preparation of figures, and Ms. Wendy Carlton for expert secretarial assistance. This work was supported by U.S. Public Health Service-NIH Grants NS-26265 to B.G.G. and NS-24054 to W.C.M.

Correspondence should be addressed to Bruce G. Gold, Ph.D., Center for Research on Occupational and Environmental Toxicology, L606, The Oregon Health Sciences University, 3181 S.W. Sam Jackson Park Road, Portland, OR 97201.

- Present address: Program in Neurosciences, Gould-Simpson 611, University of Arizona, Tucson, AZ 85721 .

Copyright (c) 1991 Society for Neuroscience $0270-6474 / 91 / 110943-13 \$ 03.00 / 0$
}

NGF treatment did not prevent the atrophy of motor fibers in the proximal ventral root.

In the second experiment, 2 antisera to mouse NGF were given daily into the footpad for 11 or $12 \mathrm{~d}$; control animals were given normal goat serum. Quantitation of axonal calibers in the L5 DRG demonstrated that mean axonal area and shape factor were significantly $(p<0.05)$ reduced by $14 \%$ and $17 \%$ respectively. The axoplasm of atrophic fibers demonstrated a paucity of NFs. Large $(\geq \mathbf{4 0} \mu \mathrm{m})$ and small $(<\mathbf{4 0}$ $\mu \mathrm{m})$ neuronal cell bodies in the L5 DRG demonstrated a 2.6and 2.4-fold increase, respectively, in the number of neurons exhibiting nuclear eccentricity. The effect was selective in that motor-nerve fibers in the L4 and L5 ventral roots and anterior horn cells in the lumbar spinal cord appeared normal.

The results suggest that NGF regulates axonal caliber and nuclear localization in sensory neurons in the adult rat DRG. Interruption of the target-derived supply of NGF may initiate some components of the axon reaction in DRG neurons.

Nerve transection (axotomy) of peripheral nerve fibers results in a stereotypic pattern of morphological responses as well as a reordering of protein synthesis in the neuronal perikaryon, termed the axon reaction (for reviews, see Lieberman, 1971; Price et al., 1984). The mechanism(s) by which the perikaryal response to axonal injury is initiated is unknown. However, an alteration involving a yet unidentified retrogradely transported "trophic" signal from the periphery may be involved (Kristensson and Olsson, 1975). Previous studies from this laboratory (Gold ct al., 1986; Gold and Dark, 1988a,b) have focused on the regulation of one component of the axon reaction: the production of somatofugal axonal atrophy arising from a decrease in neurofilament (NF) content in the axon. Studies on the regulation of axonal caliber may provide insight into how the axon reaction is initiated in peripheral nerve fibers.

Neurofilaments are the major determinants of axonal caliber in large myelinated fibers (Friede and Samorajski, 1970; Hoffman et al., 1984, 1987). Axonal caliber is tightly coupled to the level of NF synthesis within the neuronal perikaryon. It has been suggested (Lasek, 1988) that the regulation of NF synthesis (and, presumably, axonal caliber) is under the control of both intrinsic (genomic) and extrinsic (trophic) factors. The most compelling evidence in favor of extrinsic regulation of axonal caliber and NF synthesis comes from studies of transected (i.e., axotomized) nerve fibers.

Following axotomy, there is a marked reduction in NF synthesis (Hoffman et al., 1987; Wong and Oblinger, 1987; Gold- 
stcin ct al., 1988; Oblinger and Lasek, 1988; Tetzlaff et al., 1988), resulting in decreased delivery of NFs to the proximal axon (Hoffman and Lasek, 1980). Axonal atrophy ensues (Hoffman et al., 1984; Pfeiffer and Friede, 1985), reflecting the linear relationship between NF content and cross-sectional area of the axon (Friede and Samorajski, 1970; Hoffman et al., 1984). Atrophy, which begins near the neuronal perikaryon, advances down the nerve at the rate of slow axonal transport (hence the term somatofugal axonal atrophy). Return to normal caliber is dependent upon reconnection of the axon with its target tissue; if regeneration is prevented, atrophy persists (Hoffman et al., 1984). Interestingly, previous studies from our laboratory (Gold et al., 1986; Gold and Dark, 1988a,b) suggest that initiation of somatofugal atrophy may proceed without actual interruption of nerve-muscle contact. These observations suggest that a "trophic" factor retrogradely transported from the target organ functions to regulate NF content and axonal caliber. The studies described in this paper were directed at testing this hypothesis and determining whether a known sensory neurotrophic factor serves this function.

NGF is the best-characterized neurotrophic factor (for reviews, see Thoenen and Barde, 1980; Purves, 1988) and is synthesized and released in the targets of NGF-responsive neurons; recently, 2 new neurotrophic factors have been independently identified that together appear to constitute an NGF gene family (Leibrock et al, 1989; Hohn et al., 1990; Maisonpierre et al., 1990). Sympathetic and sensory neurons are dependent upon continued supply of NGF for survival and growth during development. Moreover, prenatal administration of NGF reduces naturally occurring death of dorsal root ganglia (DRG) sensory neurons (Hamburger et al., 1981). Trophic dependence of sensory neurons on NGF appears to extend into early postnatal life, as evidenced by the finding that axotomy leads to a loss of up to $50 \%$ of sensory neurons in neonatal rats (Yip et al., 1984), which can be prevented by administration of exogenous NGF (Bondok and Sansone, 1984; Yip et al., 1984; Miyata et al., 1986). In addition, administration of NGF antiserum to newborn rats results in a reduction in the number of DRG neurons (Yip et al., 1984).

Sensory neurons appear to lose their dependence on NGF for survival during postnatal development; administration of NGF antiserum fails to produce detectable cell death in adult DRG (Gorin and Johnson, 1980; Schwartz et al., 1982). However, NGF may continue to have an important regulatory role in mature sensory neurons. NGF is specifically taken up along the length of both peripheral and central processes of sensory neurons (Richardson and Riopelle, 1984) and is transported retrogradely to the neuronal perikaryon (Stockel et al., 1975); approximately $40 \%$ of the neurons in the adult DRG display high-affinity NGF receptors (Richardson et al., 1986; Verge et al., 1989a), which appear to be responsible for transport of NGF to the neuronal perikaryon (see Discussion). NGF regulates gene expression and content of substance $P$ and calcitonin gene-related peptide in DRG neurons (Lindsay and Harmar, 1989; Verge et al., 1989b). NGF deprivation also results in marked reductions in substance P levels in DRG (Schwartz et al., 1982) and atrophy of DRG neuronal perikarya (Rich et al., 1987). Moreover, continuous infusion of NGF to the proximal stump of a transected sciatic nerve mitigates some of the morphological, biochemical, and electrophysiological alterations in axotomized DRG neuronal perikarya (Schwartz et al., 1982; Fitzgerald et al., 1985; Otto et al., 1987; Rich et al., 1987). In addition, the dramatic (20\%) reduction in the number of highaffinity NGF receptors on sensory neurons following axotomy can be prevented by administration of NGF to the proximal stump (Verge et al., 1989a). Taken together, these findings suggest that NGF continues to act on intact adult (mature) sensory nerves; the findings following axotomy are consistent with a role for NGF provided by retrograde transport.

Two approaches have been used to test directly the hypothesis that NGF is the target-derived "trophic" factor required for the maintenance of axonal caliber in NGF-responsive sensory neurons of the adult rat. First, we asked whether continuous delivery of NGF to the proximal stump of an axotomized nerve would prevent somatofugal axonal atrophy in lumbar DRG neurons. Second, NGF antiserum was administered to adult rats to examine whether NGF deprivation would induce somatofugal axonal atrophy in intact sensory neurons; neuronal perikarya were also examined for evidence of nuclear eccentricity and chromatolysis. Taken together, the results strongly suggest that NGF functions in vivo to control axonal caliber, NF content, and nuclear localization in DRG sensory neurons of the adult rat.

Portions of the work presented in this paper have appeared in abstract form (Matheson and Gold, 1989; Matheson et al., 1989).

\section{Materials and Methods}

Biological agents. Mouse NGF was prepared by ion-exchange chromatography as described (Mobley et al., 1986). Cytochrome C and normal goat serum were purchased from Sigma Chemical Company, St. Louis, MO. Two NGF antisera were used in this study: Rabbit antimouse NGF (RAM) was raised against mouse NGF purified by ionexchange chromatography followed by HPLC (Mobley et al., 1986); goat anti-mouse NGF (GAM) was raised against mouse NGF prepared by ion-exchange chromatography followed by gel filtration in $2 \mathrm{~N}$ acetic acid in Sephadex G-75 (Mobley et al., 1986). For both antisera, the only immunostained bands in Western blots (Davis et al., 1986) of soluble mouse submaxillary gland protein were those expected for NGF.

Biological assay of NGF antiserum activity. Biological activity of NGF antisera was assessed in in vitro assays using embryonic chick DRG, as previously described (Longo et al., 1990). Briefly, antisera were incubated in the assay at varying dilutions. At a dilution of $1: 255$, the NGF effect on neurite outgrowth was inhibited by $95.2 \pm 2.9 \%$ and $95.5 \pm$ $3.5 \%$ for GAM $(n=6)$ and RAM $(n=5)$, respectively. Assays in which preimmune rabbit or goat serum were incubated demonstrated no effect on neurite outgrowth.

NGF administration to a transected sciatic nerve. Four 9-week-old male Sprague-Dawley rats were anesthetized with chloral hydrate (400 $\mathrm{mg} / \mathrm{kg}$, i.p.), the left sciatic nerve was transected at midthigh, and the proximal stump was teased into a conical cuff connected to an osmotic minipump (Alza, Palo Alto, CA) filled with $10 \mu \mathrm{g} \mathrm{NGF}$ in $0.2 \mathrm{ml}$ phosphate-buffered saline $(\mathrm{pH}, 7.4)$. Cuffs were sutured to the overlying muscle, and the pump was implanted subcutaneously. In the axotomized control group, 3 animals underwent identical surgical manipulation; pumps were filled with $10 \mu \mathrm{g}$ cytochrome $\mathrm{C}(n=2$; a protein with a molecular weight and isoelectric point similar to NGF) or saline $(n=$ 1). At the end of each experiment (see Tissue fixation and preparation, below), the sciatic nerves were dissected to verify that the nerve was still contained within the cuff. In 1 of the NGF-treated animals, the nerve had dislodged from the cuff; the data from this animal were not included in subsequent analyses.

$N G F$ antiserum administration to normal anirrals. Four 4-week-old male Sprague-Dawley rats were injected daily for $11 \mathrm{~d}$ with $\operatorname{RAM}(n=$ 1) or for $12 \mathrm{~d}$ with $\mathrm{GAM}(n=3), 0.5 \mu \mathrm{l} / \mathrm{gm}$ body weight, s.c., into the left footpad (Hulsebosch et al., 1987). Age-matched control rats $(n=$ 4) were injected daily with the same volumes of normal goat serum.

Tissue fixation and preparation. Two weeks following transection and pump implantation, NGF-treated and control rats, together with 3 agematched 11 -week-old normal rats, and 2 wks following the first injection of antiserum, NGF antiserum-treated and control rats, were anesthetized with chloral hydrate $(400 \mathrm{mg} / \mathrm{kg}$, i.p.) and perfused through the ascending aorta with $5 \%$ glutaraldehyde in $0.1 \mathrm{M}$ sodium phosphate 
Table 1. Axonal and myelin sheath parameters following transection and continuous infusion of NGF to the sciatic nerve

\begin{tabular}{lllll} 
Group & $\begin{array}{l}\text { Axonal area } \\
\left(\mu \mathrm{m}^{2}\right)\end{array}$ & $\begin{array}{l}\text { Axonal } \\
\text { perimeter } \\
(\mu \mathrm{m})\end{array}$ & MST $(\mu \mathrm{m})$ & Shape factor $(\varnothing)$ \\
\hline Normal $(n=3)$ & $16.7 \pm 0.44$ & $14.7 \pm 0.21$ & $1.20 \pm 0.015$ & $0.79 \pm 0.004$ \\
Transection plus NGF $(n-3)$ & $14.8 \pm 0.32^{*}$ & $14.8 \pm 0.17$ & $1.20 \pm 0.012$ & $0.71 \pm 0.004^{*}$ \\
Axotomized control $(n=3)$ & $13.1 \pm 0.25^{* *}$ & $14.9 \pm 0.15$ & $1.17 \pm 0.012$ & $0.66 \pm 0.004^{* *}$
\end{tabular}

A total of 1200, 1964, and 1956 fibers (400-665 per DRG) were analyzed in normal, transected NGF, and control axotomized groups, respectively. Mean cross-sectional area from the axotomized control (see Results) and transection plus NGF groups is reduced by $22 \%$ and $11 \%$, respectively, and mean shape factor $[\varnothing=($ observed area of axon)/(area of a circle with the same perimeter)] is reduced by $15 \%$ and $10 \%$ from normal values, respectively. Mean axonal perimeter and MST are the same for all 3 groups, indicating that these represent similar-sized fiber populations. Values are given as mean $\pm \mathrm{SEM} ; n=$ number of animals.

$* p<0.05$, compared to control axotomized and normal groups.

** $p<0.05$, compared to transected plus NGF and normal groups.

buffer ( $\mathrm{pH}, 7.2)$. The following tissues were sampled: DRG, spinal cord, and dorsal and ventral roots at the L4 and L5 levels; sciatic nerve; and soleus, medial gastrocnemius, and interosseus muscles (NFG antiserum). Tissues were postfixed in osmium tetroxide, dehydrated in a graded series of alcohol, and embedded in Epon/Araldite. Thick sections $(1 \mu \mathrm{m})$ were stained with toluidine blue; thin sections were stained with uranyl acetate and lead citrate and examined in a Zeiss 10CA or Joel CX II electron microscope.

Morphometric analysis. Analysis of axonal caliber was made for sensory fibers in the L5 DRG. Because axonal calibers differ between peripherally and centrally projecting portions of sensory axons (Suh et al., 1984), sections were selected only from the centrally projecting (i.e., dorsal root) side of the DRG; care was taken to insure that tissue sections for analysis were from comparable levels of the dorsal root in each DRG.

For each animal, axonal perimeter and axonal area measurements were made by tracing the inner aspect of the myelin sheath on photographic prints (final magnification, 1320x) of 400-750 fibers (NGF pump experiments) and 300-350 fibers (NGF antiserum experiments) using a Houston Instrument HI-PAD digitizing tablet connected to an IBM XT computer with appropriate software (BIOQUANT IV, R\&M Biometrics, Nashville, TN). Axonal diameters were calculated from these measurements. Axonal shape factor ( $\varnothing$, a measure of circularity) was also calculated from the data using the formula $\varnothing=4 \pi$ area/perimeter ${ }^{2}$. The outer aspect of the myelin sheath was also traced and used to determine nerve fiber perimeters, area, and diameter. Myelin sheath thickness (MST) was calculated from these data using the formula MST - (fiber perimeter - axonal perimeter)/2; this equation has been shown to accurately define morphometric relationships in normal and atrophic nerve fibers (Gillespie and Stein, 1983). Cumulative histograms were constructed from these data.

NF counts and density were determined on photographic prints (magnification, 25,000 $\mathrm{x}$ ) of the axoplasm of randomly selected, large myelinated fibers (8-10 fibers/grid) from the dorsal root in the DRG; only those fibers cut in cross-section were chosen for analysis. For large fibers, all NFs from a representative field (representing approximately $60-75 \%$ of total axonal area) of the axoplasm of large fibers were counted, the density $\left(\mathrm{NFs} / \mu \mathrm{m}^{2}\right)$ was calculated, and the total number of NFs was extrapolated from the area of the axon. For small myelinated fibers, all NFs within the axon were counted from photographic prints (magnification, 20,000-30,000x) of randomly selected fibers (3-5 fibers/grid). Total number of NFs was thereby determined, and the density (NFs/ $\mu \mathrm{m}^{2}$ ) was calculated from axonal areas (see Gold et al., 1985).

Semiquantitative analysis of nuclear eccentricity. Nuclear eccentricity was determined on photographic prints (final magnification, 1320 $\times$ ) of cross-sections of L5 DRG using semiquantitative methods. The investigator was blinded to the identity of the micrographs (e.g., experimental or control). Each cell body demonstrating a nucleolus was rated on a scale of 1 to 4 , with 1 being centered and 4 being markedly eccentric nucleus. Neuronal cell bodies were divided into 2 groups (large and small) based upon cell body diameter. Diameters were calculated from area measurements performed by tracing the perimeter of the cell body using a Houston Instrument HI-P $\triangle D$ digitizing tablet interfaced with an IBM XT computer and BIOQUANT IV software (R\&M Biometrics, Nashville, TN). Large cell bodies were arbitrarily defined as those with diameters $\geq 40 \mu \mathrm{m}$, and small (including medium) cell bodies were defined as those with diameters $<40 \mu \mathrm{m}$ (see Verge et al., 1989a). The percentage of large and small cell bodies judged to contain eccentric nuclei (i.e., those rated as either 3 or 4) was calculated for each DRG.

Statistical analysis. Mean values for axonal area, axonal perimeter, myelin sheath thickness, and shape factor for sensory fibers from normal animals and from NGF-treated and control axotomized nerves were compared using a 1 -way ANOVA followed by Student's $t$ test. As expected, these fibers displayed a slightly skewed distribution owing to the presence of multiple populations of different-sized fibers. Thus, we calculated a Mann-Whitney $U$ statistic because this test makes no assumptions about the shape of the distribution. These tests confirmed the results of the ANOVA and Student's $t$ test, and these latter values are discussed herein.

Regression analysis was performed to test the relationship between NF number and axonal area and between NF number and axonal perimeter for NGF-treated and control axotomized nerves. Mean values for NF densities and total number of NFs divided by axonal perimeter were compared using Student's $t$ test.

RAM and GAM produced equivalent alterations on axonal calibers (see Fig. 2). Thus, data from these 2 groups were combined. One rat treated with GAM demonstrated prominent perfusion artifacts (e.g., poor fixation of the myelin sheath), making quantitative analysis unreliable. Thus, this animal, along with 1 randomly chosen control animal, was not included in the data analysis. The incidence of cell bodies demonstrating eccentric nuclei were compared for large and small cell bodies using $\chi^{2}$ analysis.

All values are given mean \pm SEM.

\section{Results}

The effect of continuous NGF infusion on axonal caliber following sciatic nerve transection

\section{Light microscopic studies}

Iransection of the sciatic nerve produced marked axonal atrophy of dorsal roots in the L4 and L5 DRG (Hoffman et al., 1984; Pfciffer and Friede, 1985; Fig. 1). Fibers from the transected control nerve (not shown) and the 2 transected nerves treated with cytochrome $\mathrm{C}$ (Fig. 1C) were indistinguishable from each other; for morphometric study (see below), data from these 3 animals were combined into a single group (i.e., axotomized control group). Fibers from the axotomized control group appeared smaller in caliber compared to fibers from age-matched normal animals (Fig. 1A); many fibers were knuckled and had inappropriately thick myelin sheaths relative to their cross-sectional profiles. NGF-treated transected nerves (NGF-treated nerves) exhibited some similarly shrunken fibers (Fig. 1B). However, atrophic profiles were less numerous and fibers appeared more circular in shape than those from the control axotomized group (Fig. 1C). NGF treatment had no apparent effect on ax- 

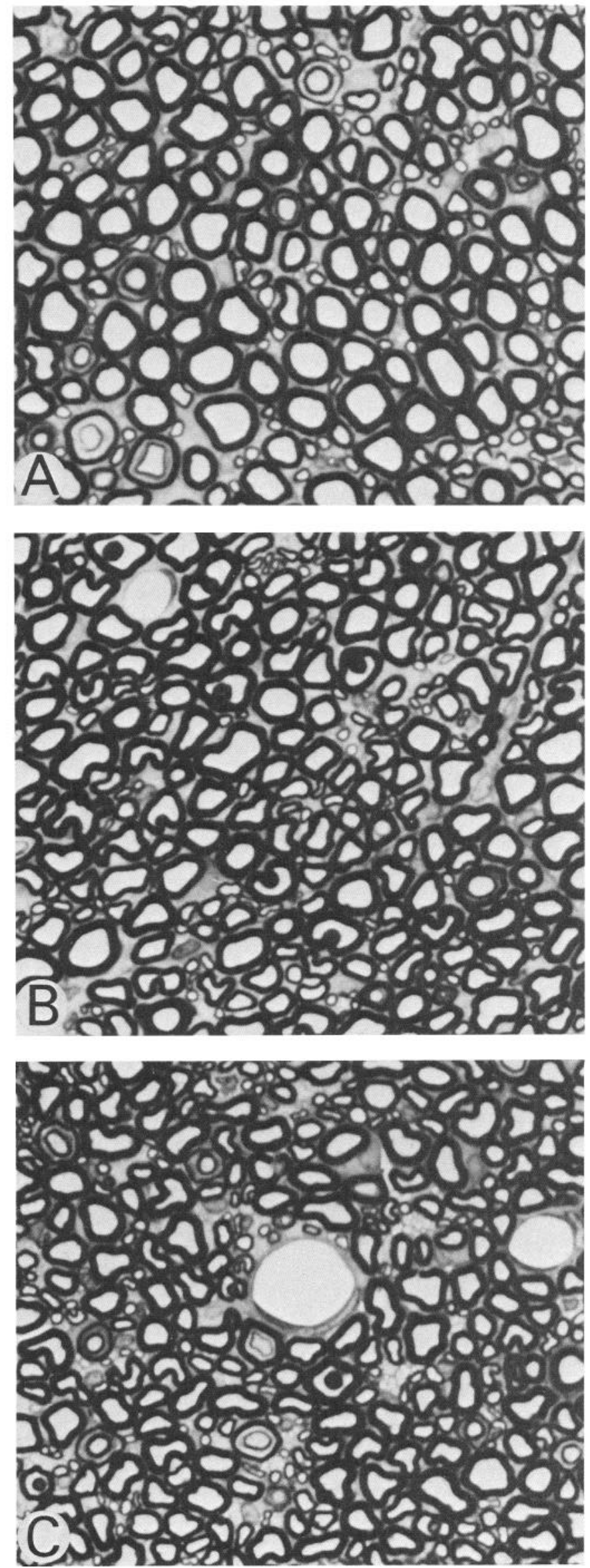

otomy-induced axonal atrophy of motor fibers in the proximal portions of the L4 and L5 ventral roots (not shown).

\section{Morphometric studies}

Cumulative distributions of axonal areas of dorsal root fibers in the L5 DRG demonstrated a shift towards smaller calibers in the control axotomized group compared to normal animals (Fig. 2); mean axonal area was reduced by $22 \%$ from the normal (Table 1). Dorsal root fibers from NGF-treated nerves demonstrated a more modest shift in axonal calibers (Fig. 2); mean axonal area in NGF-treated nerves was reduced by only $11 \%$ from the normal (Table 1). Moreover, fibers from NGF-treated nerves were significantly $(p<0.05)$ larger in axonal caliber than fibers from the axotomized control group (Table 1). A similar effect was observed from axonal shape factors, which were significantly ( $p<0.05)$ larger (i.e., more circular in shape) in NGFtreated nerves than those from the axotomized control group (Table 1); compared to age-matched normal animals, mean values were reduced by $15 \%$ in the control axotomized group and $10 \%$ in the NGF-treated nerves. Axonal perimeter and MST were unchanged, indicating that equivalent samples of fibers were measured in each group.

\section{Ultrastructural studies}

Ultrastructural examination suggested that NF packing density was similar in axoplasm of atrophic sensory fibers from the control axotomized and NGF-treated axotomized nerves (not shown). Quantitation of NF numbers demonstrated a linear relationship for the total number of NFs and axonal area for both groups; the slope (i.e., NF density) was not significantly different in fibers from the axotomized control group and NGFtreated nerves (Fig. $3 A$ ); NF density was the same in fibers from these 2 groups (Table 2). When NF number was plotted against axonal perimeter, the relationship was also linear (Fig. 3B). However this analysis gave a greater slope in NGF-treated nerves (Fig. 3B; Table 2); because axonal perimeters were unchanged from control values (Table 1), this gives an index of the original (i.e., preaxotomized) axonal caliber of each fiber. This analysis demonstrated that a given fiber from an NGF-treated nerve contains more NFs in its axoplasm than a corresponding fiber (i.e., one with the same axonal perimeter, albeit smaller axonal area) from an axotomized control nerve.

The effects of NGF antiserum administration in intact neurons

\section{Light and electron microscopic observations}

Similar alterations were observed in animals treated with either RAM or GAM; the only difference noted was that axonal atrophy extended slightly (1-2 $\mathrm{mm})$ farther along the dorsal root

\footnotetext{
Figure 1. Light micrographs of dorsal root fibers in the L5 DRG from a normal 11-week-old rat $(A)$ and from rats in which the left sciatic nerve was transected at 9 weeks of age and connected to an osmotic minipump filled with either NGF $(B)$ or cytochrome $C(C)$. Sensory fibers from the cytochrome $C$-treated nerve $(C)$ appear smaller in caliber and less circular compared to those from the age-matched normal animal $(A)$. The sensory fibers from the NGF-treated nerve $(B)$ appear larger and more circular compared to those from the cytochrome C-treated nerve $(C)$, but somewhat smaller in caliber and less circular compared to fibers from the age-matched normal animal $(A)$. Magnification, $670 \times$.
} 


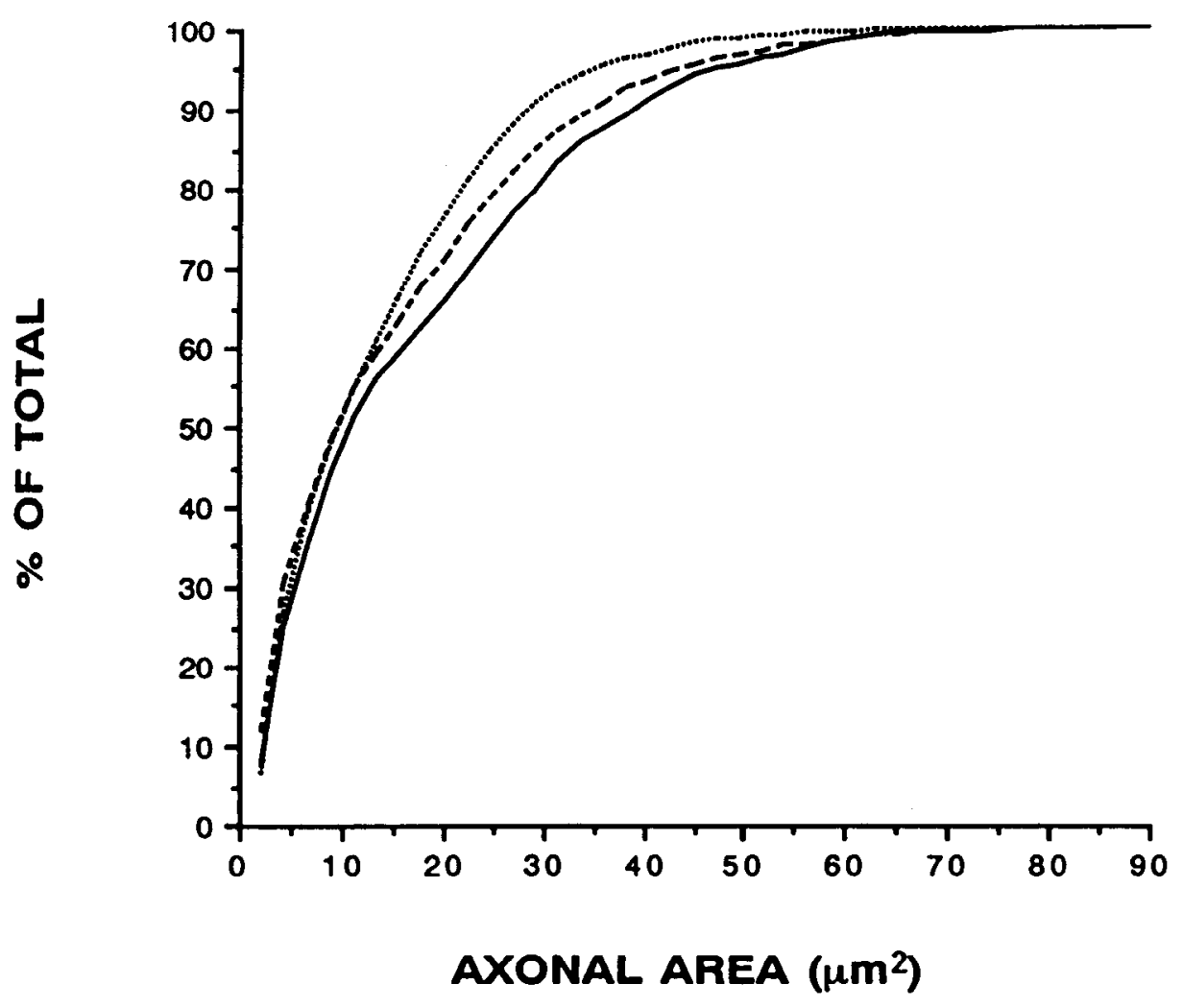

Figure 2. Comparison of cumulative histograms of axonal areas for dorsal root fibers in the L5 DRG from normal rats (solid line), NFG-treated axotomized sciatic nerves (dashed line), and control axotomized nerves (dotted line). Fibers from the control axotomized group (see Results) demonstrated a definite shift to the left (indicating the presence of smaller-caliber fibers). Although fibers from the NGF-treated nerves are smaller than those from the age-matched normal animals, the curve is shifted to the right compared to the control axotomized group. These changes are most apparent for large myelinated fibers. in the animal given RAM. Thus, data from the 2 antiserum groups were combined for morphometric analyses.

Dorsal root fibers in the L4 and L5 DRG from animals given NGF antiserum appeared smaller in caliber and less circular than fibers from control animals (Fig. 4). Ultrastructurally, these atrophic fibers demonstrated a paucity of NFs in their axoplasm (Fig. 5). A rare ( $<1 \%$ of fibers) myelin bubble in a dorsal root fiber was also observed in the DRG (not shown); these profiles arise as a nonspecific, secondary response of the myelin sheath to axonal atrophy (Spencer and Schaumburg, 1977; Griflin and Price, 1981). Neuronal cell bodies in the DRG from rats given

Table 2. NFs in sensory fibers of the L5 DRG following transection and continuous infusion of NGF to the sciatic nerve

\begin{tabular}{|c|c|c|}
\hline Group & $\begin{array}{l}\text { Density } \\
\left(\mathrm{NF} / \mu \mathrm{m}^{2}\right)\end{array}$ & $\begin{array}{l}\text { Total num- } \\
\text { ber of NFs/ } \\
\text { axonal } \\
\text { perimeter } \\
(\mathrm{NFs} / \mu \mathrm{m})\end{array}$ \\
\hline Axotomized control $(N=3)$ & $\begin{array}{l}206 \pm 9.4 \\
(n=28)\end{array}$ & $\begin{array}{l}103 \pm 10.8 \\
(n=28)\end{array}$ \\
\hline Transection plus NGF $(N=3)$ & $\begin{array}{l}220 \pm 12.8 \\
(n=28)\end{array}$ & $\begin{array}{l}164 \pm 19.4^{*} \\
(n=28)\end{array}$ \\
\hline
\end{tabular}

Total number of NFs in each fiber were divided by axonal area (density) or axonal perimeter (an index of original axonal caliber; see Results). Sensory fibers from the transected NGF-treated nerves have increased total numbers of NFs for their axonal perimeters compared to the axotomized control groups, indicating that the greater axonal calibers (see Table 1) result from an increase in NF content in the axoplasm. Values are given as mean \pm SEM. $N=$ number of animals; $n=$ number of fibers.

$* p<0.05$.
NGF antiserum appeared to contain an increased number of eccentric nuclei (Fig. 6). However, true chromatolytic neurons were not observed of this study.

These alterations were selective for sensory neurons. Motor fibers in the L4 and L5 ventral roots adjacent to the spinal cord (Fig. 7), anterior horn cells in the L4 and L5 spinal cord (not shown), and dorsal root (sensory) fibers in the contralateral DRG (not shown) appeared normal in rats given NGF antiserum. Moreover, these changes did not appear to arise secondary to axonal degeneration in the distal portions of the nerve. Ultrastructural examination of fibers in the distal sciatic nerve and intramuscular nerve branches and of sensory and motor nerve terminals in soleus, medial gastrocnemius, and interosseus muscles revealed no structural alterations in animals given injections of NGF antiserum (not shown).

\section{Morphometric studies}

Distribution of axonal area and shape factor were shifted to smaller values in animals given NGF antiserum injections (Fig. 8 ); mean axonal area was decreased by $14 \%$, and shape factor was decreased by $17 \%$; both changes were significant $(p<0.05$; Table 3). In contrast, the distributions and mean values for axonal perimeter and MST were little changed from control values (Fig. 8; Table 3).

No difference was observed in the distributions of neuronal cell body areas in the L5 DRG between the experimental and control groups (data not shown). In control animals, approximately $20 \%$ of both large and small neuronal cell bodies (see Materials and Methods) demonstrated nuclear eccentricity (Table 4). The proportion of large and small neuronal cell bodies with eccentric nuclei in rats given NGF antiserum was increased 2.6-fold and 2.4-fold, respectively (Table 4). 

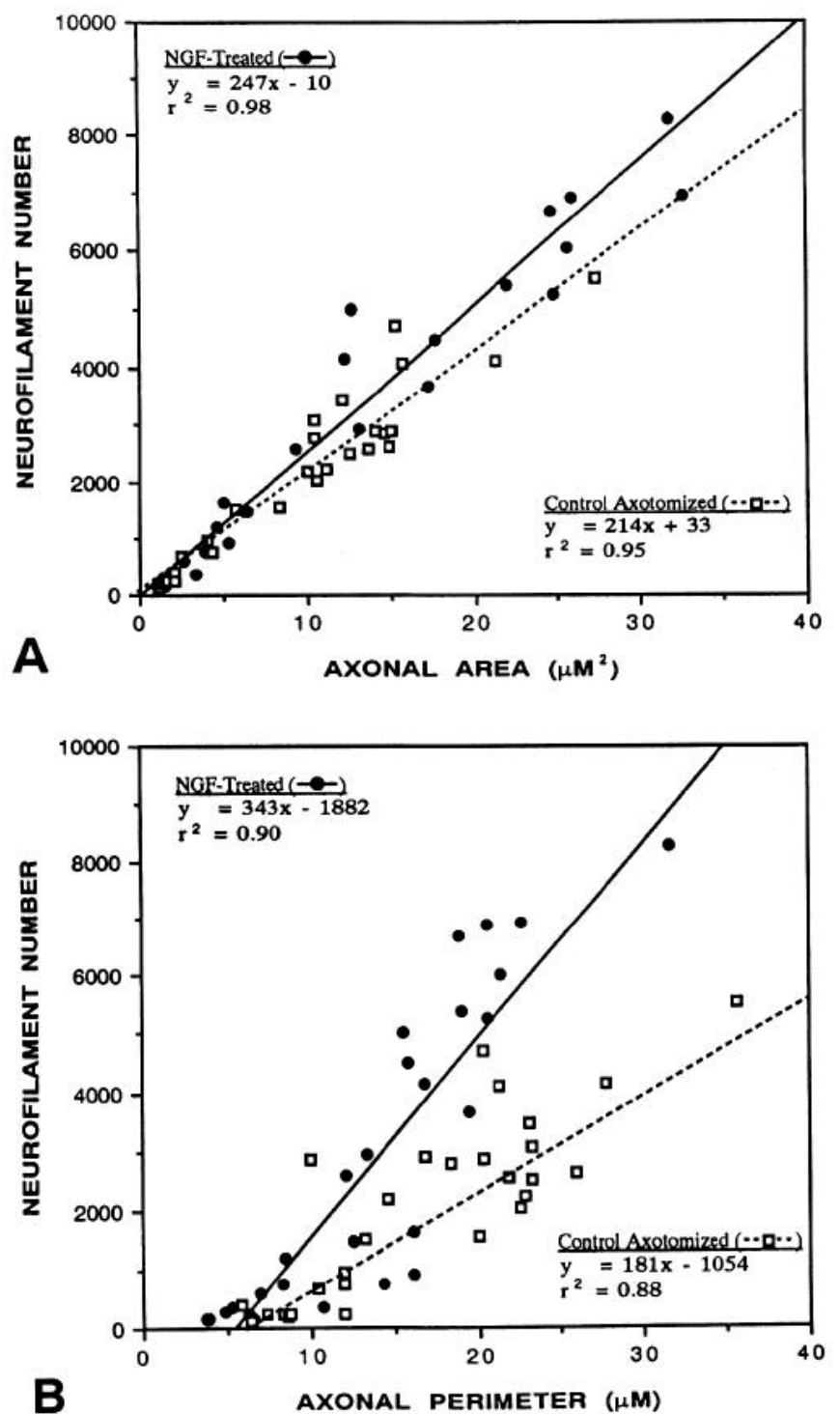

Figure 3. Plots of NF number versus axonal area $(A)$ and axonal perimeter $(B)$ from dorsal root fibers in the L5 DRG from NGF-treated transected nerves and the axotomized control group. In $A$, NF density (slope of the line) is similar in fibers from both groups (see Table 2). However, fibers from the NGF-treated nerves demonstrate more NFs in their axoplasm compared to fibers from the axotomized control group when the NF data are plotted against axonal perimeters $(B)$; axonal perimeter gives an indication of the original (i.e., preaxotomized) axonal caliber of each fiber. Note that fibers from both groups show a similar range of axonal perimeters $(B)$, although the fibers from the NGF-treated nerves achieve greater axonal areas $(A)$; i.e., fibers from the axotomized control groups are more atrophic. $r^{2}=$ correlation coefficient.

Figure 4. Light micrographs of dorsal root fibers in the L5 DRG from 6-week-old rats given daily injections of normal goat serum $(A)$ or RAM $(B)$ or GAM $(C)$ NGF antiserum. Sensory fibers from rats given either RAM or GAM NGF antiserum appear smaller in caliber and less circular compared to those from the age-matched serum-treated control animal. All sections are from the centrally projecting side of the DRG. However, in $C$ the fibers are located in the neuronal cell body region (asterisks) of the DRG, whereas the sections in $A$ and $B$ were taken approximately 1-2 mm distal (towards the spinal cord) to the cell bodies (see Results). Epon sections $(1 \mu \mathrm{m})$ were stained with toluidine blue. Magnification, $670 \times$.
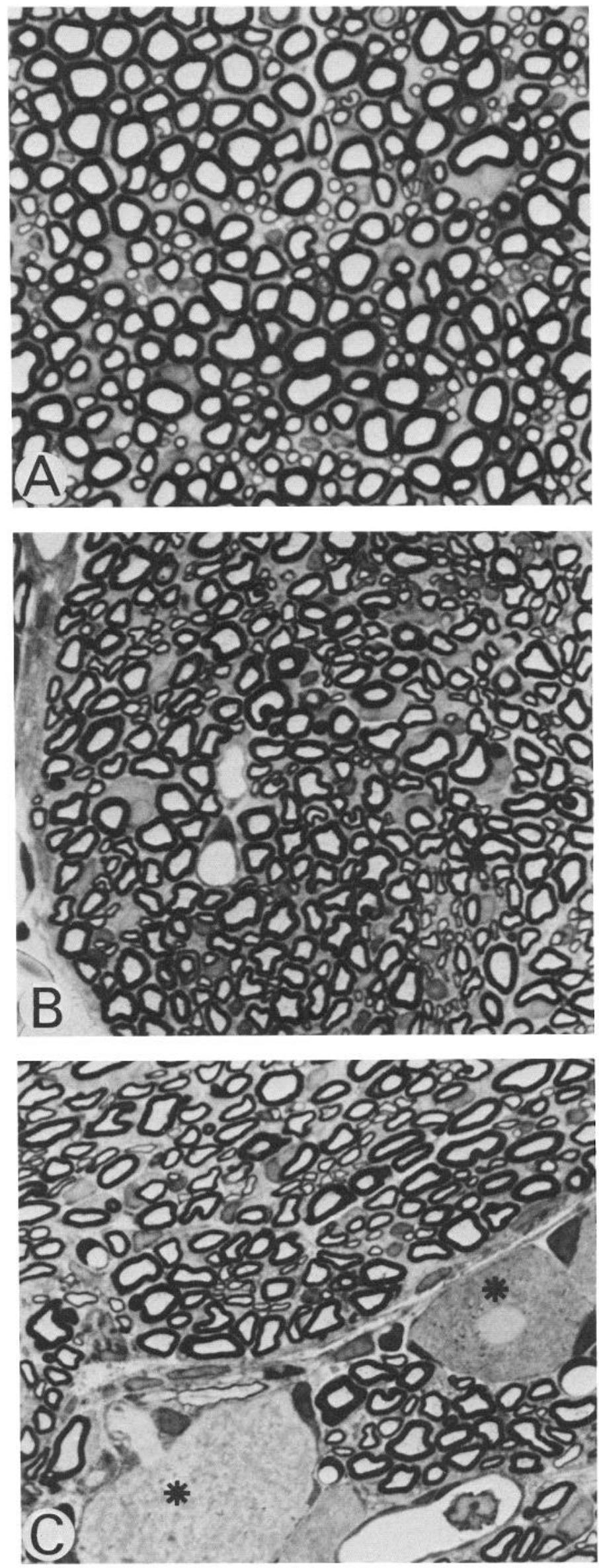

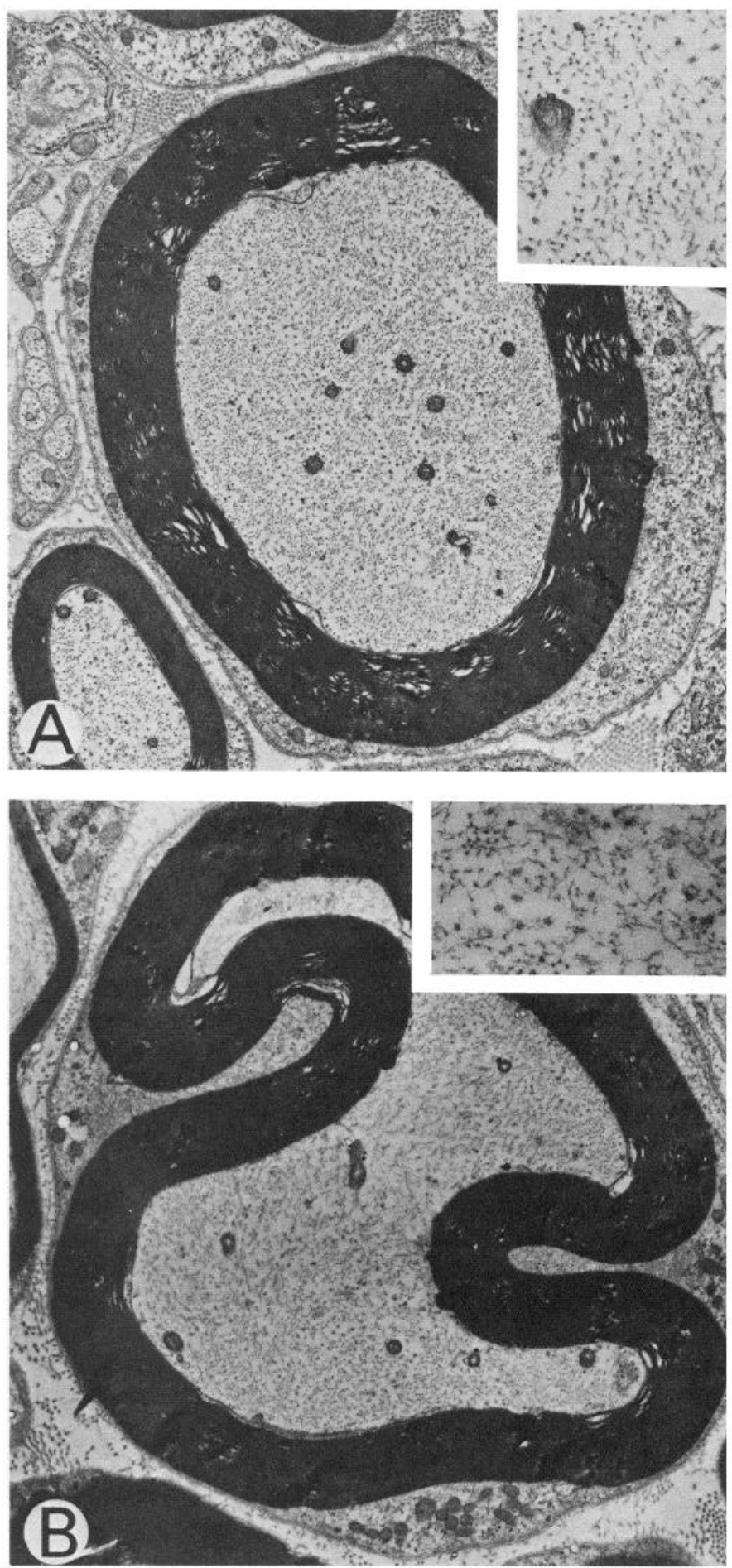

Figure 5. Electron micrographs of myelinated dorsal root fibers in the L5 DRG from an animal given normal goat antiserum $(A)$ or GAM $(B)$. The fiber from the animal given GAM shows prominent infolding of the axolemma and myelin sheath (i.e., axonal atrophy). Insets, Highpower views of axoplasm. Note the paucity of neurofilaments and relative abundance of microtubules in the axoplasm from the NGF antiserum-treated rat $(B)$, although neurofilament density appears similar to that observed in the fiber from the goat-serum-treated control animal (cf. inset in $A$ ). Magnification: $A$ and $B, 9310 \times$; insets, $21,560 \times$.
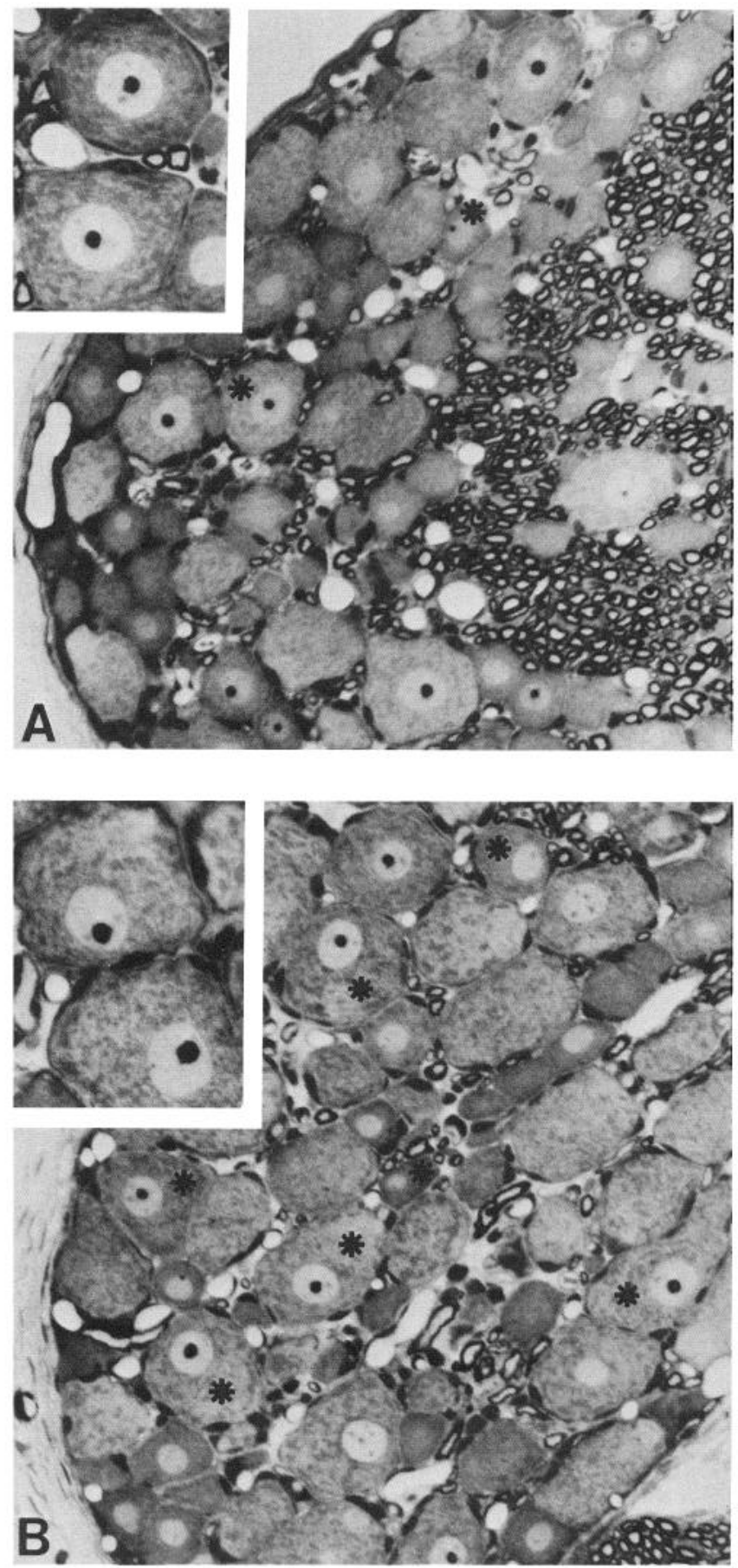

Figure 6. Light micrographs of neuronal cell bodies in the L5 DRG from 6-week-old rats given normal goat serum $(A)$ or RAM NGF antiserum $(B)$. Note the relative prominence of cell bodies with eccentric nuclei (asterisks) from the NGF antiserum-treated rat compared to the serum-treated control animal. Insets, Higher-power views of 2 normalappearing cell bodies from another rat given normal goat serum (inset in $A$ ) and 2 cell bodies with markedly eccentric nuclei from a rat given GAM (insert in $B$ ). Note prominent nucleoli in these cell bodies. Epon sections $(1 \mu \mathrm{m})$ were stained with toluidine blue. Magnification: $A$ and $B, 250 \times$; insets, $460 \times$. 

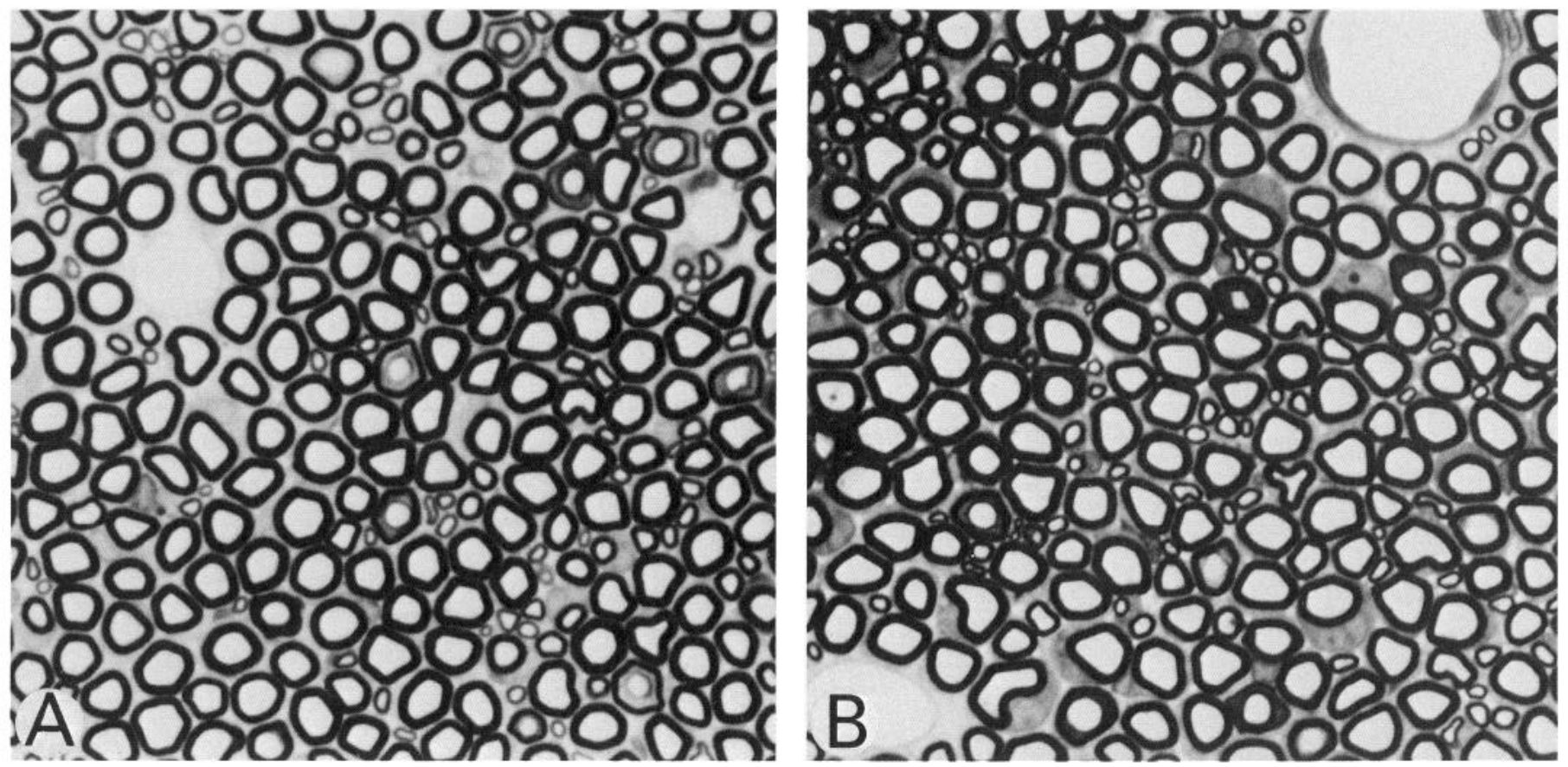

Figure 7. Light micrographs of the proximal L5 ventral root from 6-week-old rats given normal goat serum $(A)$ or RAM NGF antiserum (B). Note that the motor fibers from the NGF-antiserum-treated animal are indistinguishable from those of the age-matched serum-treated control animal. Epon sections $(1 \mu \mathrm{m})$ were stained with toluidine blue. Magnification, $670 \times$.

\section{Discussion}

The present study demonstrates that (1) continuous infusion of NGF to the proximal stump of a transected sciatic nerve partially prevents the reduction in axonal caliber and NF content in the proximal portion of lumbar DRG neurons, and (2) daily injection of NGF antiserum to normal adult rats results in decreased axonal caliber in the proximal axon and nuclear eccentricity in intact DRG neurons. This latter finding suggests that NGF not only serves to regulate axonal caliber, but also is important for other functional aspects of the neuronal perikaryon. The roles of NGF in the regulation of axonal caliber, nuclear localization, and perikaryal function are discussed separately below.

\section{Technical considerations}

The failure of NGF administration to prevent completely the production of somatofugal axonal atrophy of sensory fibers in lumbar DRG neurons in the present study may be explained by a number of technical limitations inherent in this experiment.
First, at least $50 \%$ of the sensory neurons in the rat L4 and L5 DRG lack high-affinity NGF receptors (Verge et al., 1989a) and are therefore probably not NGF responsive. Accordingly, restoration of NF mRNA levels is observed in a subpopulation of DRG neurons (i.e., those demonstrating high NGF binding) following infusion of NGF (Verge et al., 1990b). Second, though the presence of the nerve stump in the cuff was verified at the end of all experiments, the efficiency of NGF uptake by sensory axons was not ascertained; lack of continued uptake of NGF by the proximal stump during any portion of the 2-week period of study would impair delivery of NGF to the neuronal perikaryon (see Verge et al., 1989a). Third, the level of NGF administered to the proximal stump of the sciatic nerve via the osmotic minipump may not be sufficient to produce a maximal response. Fourth, it is possible, even likely, that other "trophic" factors contribute to the maintenance of neuronal homeostasis in NGFresponsive neurons; this possibility is supported by the finding that mature DRG neurons obtain non-NGF trophic support important for their survival from the spinal cord and periphery (Johnson and Yip, 1985; Davies et al., 1986). When these lim-

Table 3. Axonal and myelin sheath parameters of sensory fibers in L5 DRG following NGF antiserum administration

\begin{tabular}{lllll} 
Group & $\begin{array}{l}\text { Axonal area } \\
\left(\mu \mathrm{m}^{2}\right)\end{array}$ & $\begin{array}{l}\text { Axonal } \\
\text { perimeter } \\
(\mu \mathrm{m})\end{array}$ & MST $(\mu \mathrm{m})$ & Shape factor $(\varnothing)$ \\
\hline Control $(n=3)$ & $12.6 \pm 0.34$ & $13.2 \pm 0.18$ & $0.96 \pm 0.012$ & $0.77 \pm 0.004$ \\
NGF antiserum $(n=3)$ & $10.8 \pm 0.27^{*}$ & $13.7 \pm 0.18$ & $0.96 \pm 0.012$ & $0.64 \pm 0.005^{*}$ \\
\hline
\end{tabular}

A total of 986 and 1075 fibers (300-350 per DRG) were analyzed from control and NGF antiserum groups, respectively. Mean cross-sectional area and shape factor $[\emptyset=$ (observed area of axon)/(area of a circle with the same perimeter)] for the animals given NGF antiserum are reduced by $14 \%$ and $17 \%$ from control values, respectively. Mean axonal perimeter and MST are unaltered from control values. Values are given as mean $\pm \mathrm{SEM} ; n=$ number of animals. ${ }^{*} p<0.05$. 

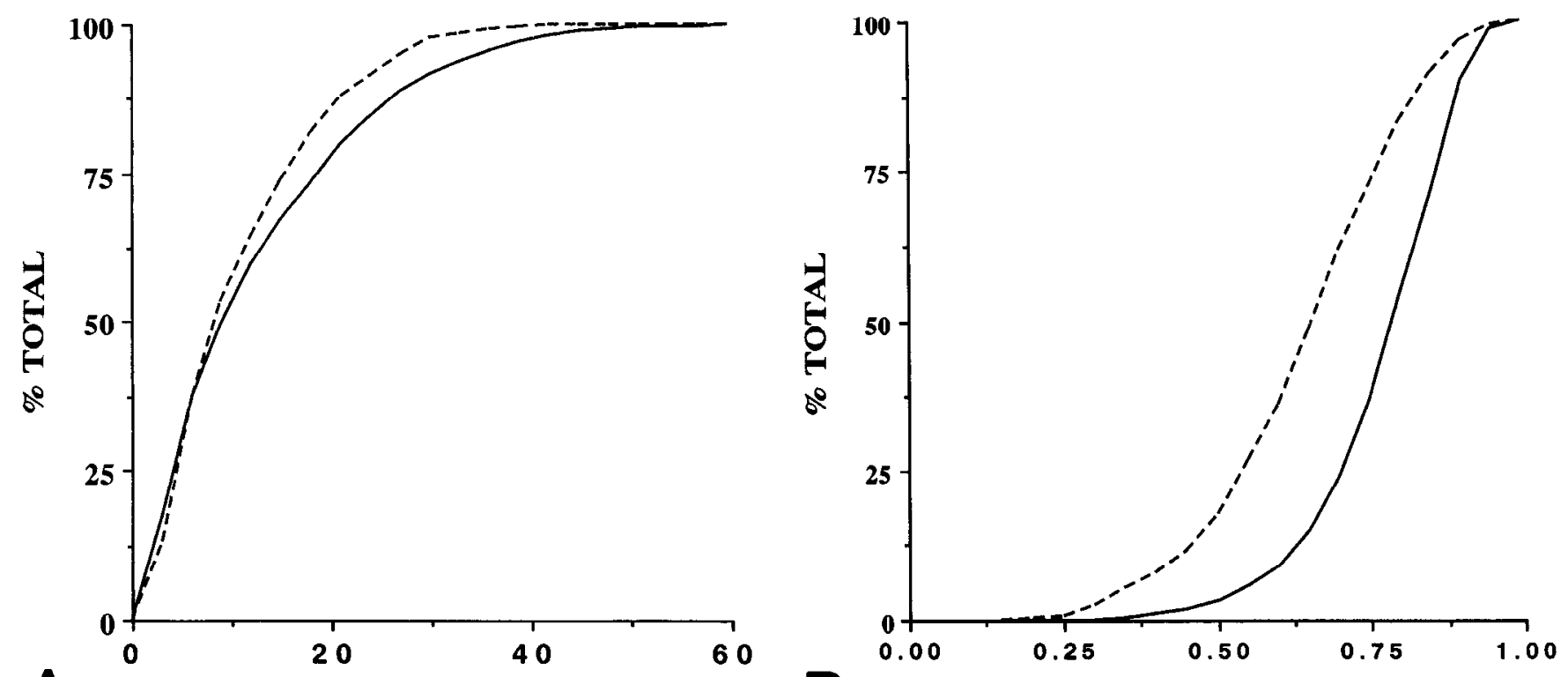

A

AXONAL AREA $\left(\mu M^{2}\right)$

B

\section{SHA PE FA CTOR}
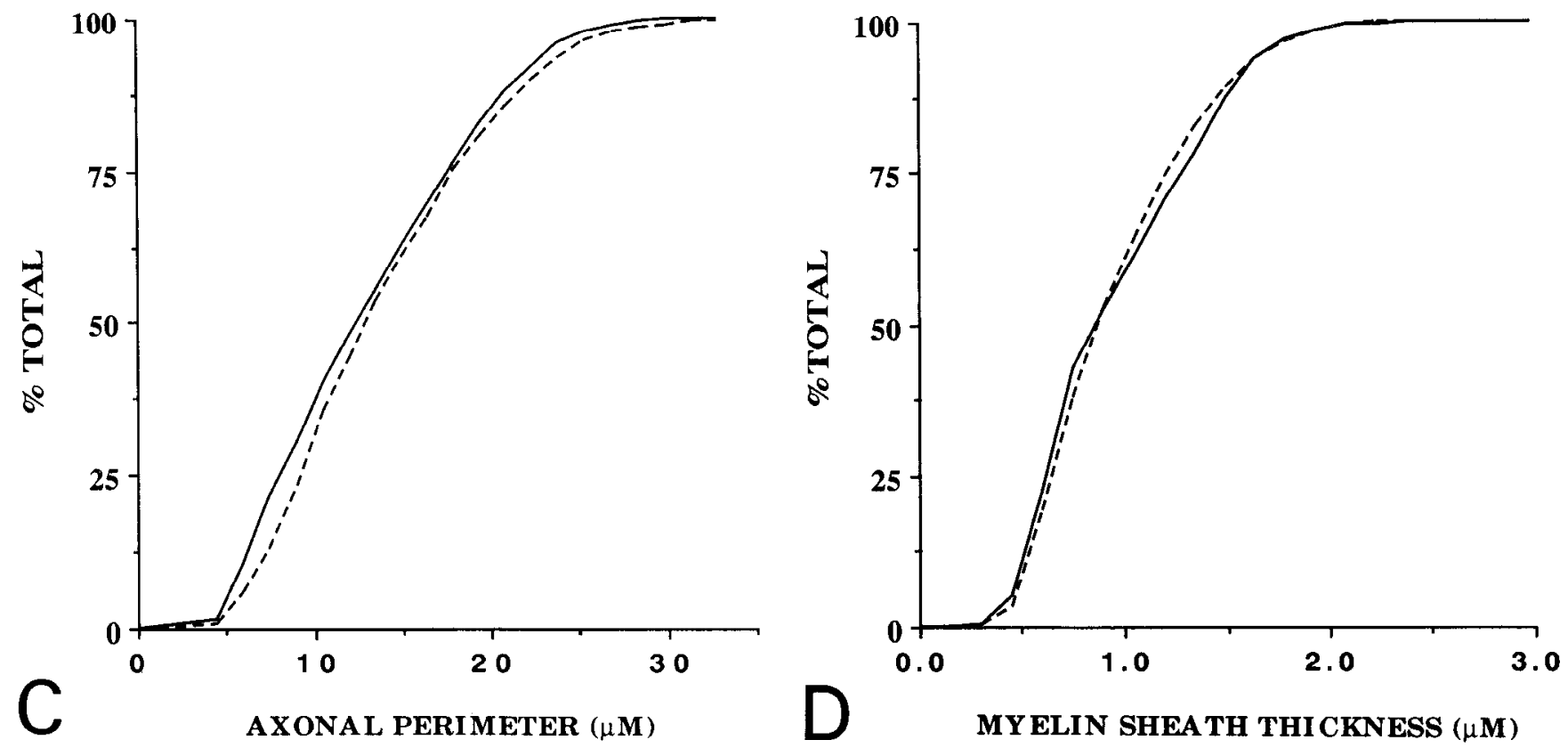

Figure 8. Comparison of cumulative histograms of axonal area $(A)$, shape factor $(B)$, axonal perimeter $(C)$, and MST $(D)$ for dorsal root fibers in the L5 DRG from 6-week-old rats given normal goat serum (solid line) or NGF antiserum (broken line). Each histogram was constructed from 986 and 1075 fibers from the serum-treated and NGF-antiserum-treated animals, respectively. Note that the axonal area and shape factor distributions are shifted to smaller values in the animals given NGF antiserum, whereas the distributions for axonal perimeter and MST appear little changed.

itations are considered together, it is thus not surprising that a significant degree of axonal atrophy was observed in NGF-treated nerves.

In addition to the NF triplet proteins (Hoffman and Lasek, 1975), sensory neurons in the rat DRG contain peripherin (Portier et al., 1984; Parysek and Goldman, 1988; Ferri et al., 1990), a type III intermediate filament protein (Leonard et al., 1988; Parysek et al., 1988). In contrast to the NF triplet proteins, peripherin synthesis is increased in large DRG neurons following axotomy (Oblinger et al., 1989). However, it is not known whether peripherin is assembled into NFs together with the NF
Table 4. Incidence of eccentric nuclei in large and small sensory neurons in the L5 DRG following NGF antiserum administration

\begin{tabular}{lll} 
Group & $\begin{array}{l}\text { Large neurons } \\
(\geq 40 \mu \mathrm{m})\end{array}$ & $\begin{array}{l}\text { Small neurons } \\
(<40 \mu \mathrm{m})\end{array}$ \\
\hline Control $(n=3)$ & $16 / 77(20.8 \%)$ & $37 / 208(17.8 \%)$ \\
NGF antiserum $(n=3)$ & $53 / 99(53.5 \%)^{*}$ & $97 / 226(42.9 \%)^{*}$
\end{tabular}

This table shows the number of cell bodies demonstrating eccentric nuclei out of the total number of cell bodies counted in the DRG (see Materials and Methods); $n=$ number of animals.

$* p<0.05$, compared to corresponding control value ( $\chi^{2}$ test). 
triplet proteins or exists as its own intermediate filament structure in neurons demonstrating coexpression of these intermediate filament proteins. In the latter case, quantitation of "NFs" in the axoplasm of axotomized DRG neurons in the present study could have included peripherin filaments. This would result in an underestimation of the degree of reduction in NF (intermediate filaments composed of the NF triplet proteins) content in axotomized DRG neurons.

A recent study demonstrated a reduction in MST in dorsal root fibers following subcutaneous injection of NGF antibodies (Urschel and Hulsebosch, 1990). The lack of an alteration in MST noted in the present study may be due to our use of older (young adult) rats with well-developed myelin sheaths. In addition, these investigators did not observe axonal atrophy. This inconsistency with our findings may be due to an apparent lower potency of their NGF antiserum or differences in the response of thoracic (Urschel and Hulsebosch, 1990) versus lumbar (present study) DRG neurons to NGF antiserum.

The mechanism by which NGF antiserum produces its effects in vivo has not been addressed in the present study. The most likely explanation is that subcutaneous injection of the antiserum into the footpad produces a decrease in the amount of NGF in the target tissue, resulting in a reduction in the retrograde axonal transport of NGF to the neuronal perikaryon. The structural integrity of sensory afferent terminals and the lack of any alterations in motor neurons argue against a nonspecific complement-mediated mechanism in the production of the alterations observed in the present study.

\section{Regulation of axonal caliber by NGF}

The development of large myelinated nerve fibers, enabling attainment of faster conduction velocities, has played an important role in the evolution of larger species of animals. However, little is known about how axonal caliber is controlled in individual nerve fibers. The major finding of the present study is that axotomy-induced axonal atrophy and decreased NF content in the proximal axon can be prevented by exogenous NGF, and conversely, that administration of NGF antiserum to normal animals produces somatofugal axonal atrophy in NGF-responsive sensory fibers in lumbar DRG neurons of the adult (mature) rat.

The present study does not address the issue of how NGF acts to increase axonal caliber in NGF-responsive neurons. However, our findings suggest that the larger axonal calibers in fibers from the NGF-treated nerves arise from an increased number of NFs in the axoplasm. This proposal is consistent with the observation that NFs are the major determinants of axonal caliber in large myelinated fibers (Friede and Samorajski, 1970; Hoffman et al., 1984). Thus, we suggest that delivery of NGF to the proximal stump of an axotomized sciatic nerve reduces the degree of axonal atrophy by preventing the axotomyinduced downregulation of NF synthesis in NGF-responsive sensory neurons; increased axonal caliber and NF content is the structural correlate of this change in NF gene expression. This hypothesis is supported by a recent study (Verge et al., 1990b) demonstrating that continuous infusion of NGF mitigates the axotomy-induced reduction in NF mRNA levels in NGF-responsive sensory neurons. Moreover, our findings demonstrating an alteration in NF content and axonal caliber in the proximal axon suggest that increased translation of NF mRNA occurs, leading to increased delivery of NFs to the axon.
Taken together, these studies provide direct evidence in support of the hypothesis (Gold et al., 1986; Hoffman et al., 1987; Lasek, 1988) that the target tissue produces a "trophic" substance that controls axonal caliber, and that extrinsic factors regulate NF gene expression in neurons of the PNS; the recent demonstration that axonal caliber of sympathetic axons is regulated by target size (Voyvodic, 1989) and, presumably, the amount of "trophic" substance delivered to the neuron is also in accordance with the model proposed by Lasek (1988). Furthermore, NGF appears to be one extraneuronal "trophic" factor that regulates NF gene expression (Verge et al., 1990b) and axonal caliber (present study) in NGF-responsive sensory neurons. NGF-mediated regulation of axonal caliber in mature neurons is consistent with NGF actions in maintaining neurotransmitter levels in these cells and seems likely to be mediated by uptake and transport of NGF in sensory neurons throughout life (Richardson and Riopelle, 1984; Verge et al., 1989a).

\section{Local and remote actions of NGF in axotomized nerve fibers}

Receptors for NGF can be classified into high- and low-affinity types (see, e.g., Hosang and Shooter, 1985; Green and Greene, 1986; Verge et al., 1989a). It appears that high-affinity NGF receptors are necessary for NGF internalization and transport (Sutter et al., 1979; Bernd and Greene, 1984; Green and Greene, 1986), although the function of low-affinity receptors is less clear (Yan and Johnson, 1988). High-affinity receptors are rapidly depleted in axotomized sensory neurons (Verge et al., 1989a). Consequently, there is a decrease in retrograde transport of NGF and its high-affinity receptors to the neuronal perikaryon (Raivich and Kreutzberg, 1987).

Following axotomy, there is an increased synthesis of NGF and low-affinity receptors in Schwann cells present in the distal stump of axotomized nerves (Taniuchi et al., 1986a,b, 1988; Heumann et al., 1987; Raivich and Kreutzberg, 1987). NGF regulation in Schwann cells occurs at least in part at the level of mRNA synthesis. It appears that NGF produced in the distal stump of an axotomized nerve acts locally to promote the regeneration of axonal sprouts (see Taniuchi et al., 1988); in the distal stump, NGF may be surface-bound by the numerous lowaffinity receptors induced following axotomy, which may provide a substratum for axonal growth and chemotactic guidance (Taniuchi et al., 1986a,b, 1988). However, the amount of NGF available in the nerve is less than normal (Heumann et al., 1987), and somatofugal axonal atrophy persists until the regenerating axons contact the target organ (Hoffman et al., 1984). Inability of NGF in the distal stump to compensate fully for lost target support may be due to insufficient production by Schwann cells (Heumann et al., 1987), immobilization of NGF by low-affinity receptors on Schwann cells, or decreased NGF binding on the sprouts of severed fibers. Restoration of normal levels of highaffinity receptors and normal axonal caliber in sensory neurons that follows reinnervation may be due to normalization of 1 or more of these factors.

We propose that delivery of NGF to the proximal stump of a transected nerve provides a continued supply of NGF at a concentration sufficient to increase expression of high-affinity NGF receptors on the neurons (Lindsay et al., 1990), resulting in increased retrograde transport of NGF to the neuronal perikaryon. Subsequently, the axotomy-induced reduction in NF synthesis and delivery of NFs to the proximal axon are partially prevented. Amelioration of the effect of axotomy on axonal caliber by NGF will therefore occur only in neurons containing 
NGF receptors; this would, in part (see above), explain the apparent selective action of NGF on a subpopulation of sensory neurons (see Verge et al., 1989a, 1990h).

\section{Nuclear eccentricity}

An important finding of the present investigation is the increased incidence of eccentric nuclei in both large and small DRG cell bodies from rats treated with NGF antiserum; the involvement of both large and small cell bodies is consistent with the presence of high-affinity NGF receptors on approximately $50 \%$ of all DRG neurons regardless of cell body size (Verge et al., 1989a). Nuclear eccentricity is a prominent component of the axon reaction occurring following axotomy of peripheral nerve fibers (for reviews, see Lieberman, 1971; Price et al., 1984). Thus, the presence of eccentric nuclei suggests that administration of NGF antiserum has widespread consequences for neuronal perikaryal function. Together with the development of somatofugal axonal atrophy, the presence of eccentric nuclei in these DRG neurons implicates loss of NGF in the induction of at least these 2 components of the axon reaction in NGF-responsive sensory neurons of the adult rat. Chromatolysis, the pathological hallmark of the axon reaction (see Lieberman, 1971), was not observed in the present series of animals. However, it is possible that this alteration would be produced following more prolonged administration of NGF antiserum.

\section{Regulation of neuronal perikaryal function in sensory neurons by $N G F$}

Taken together, our results support and extend those of previous investigators that indicate that NGF serves to maintain normal (mature) perikaryal morphology and function in NGF-responsive sensory neurons (Schwartz et al., 1982; Rich et al., 1984; Fitzgerald et al., 1985; Otto et al., 1987; Lindsay and Harmar, 1989) and autonomic neurons (Nja and Purves, 1978; see also Johnson et al., 1986; Purves, 1988) in the PNS and in cholinergic neurons of the basal forebrain (Hagg et al., 1989; see Discussion in Sofroniew et al., 1990). These data indicate that NGF does not selectively regulate NF mRNA levels (Verge et al., 1990b) but may have a more generalized effect on the neuronal perikaryon. One possibility is that loss of NGF triggers a change in neuronal gene expression such that genes whose products are important for regeneration are activated; a decrease in synthesis of products important for mature function, including NF, is another aspect of this response. Alternatively, it has been proposed (Verge et al., 1990a,b) that NGF plays an indirect, permissive role by enabling NGF-receptor-containing neurons to respond to another factor directly stimulating NF gene expression; in this context, the lack of reduction in the axotomyinduced increase in GAP-43 expression by NGF infusion (Verge et al., 1990a) suggests that at least 1 component of the axon reaction may be independently regulated by a second factor. However, the ability of NGF by itself to restore NF mRNA levels (Verge et al., 1990b) and axonal caliber (present study) in transected nerve fibers argues that increased NF gene expression does not require the presence of an additional "trophic" substance lost to DRG neuronal perikarya following axotomy. Thus, we suggest that the lack of correlation between NF mRNA levels and NGF responsiveness (e.g., small NGF-responsive neurons have low NF mRNA levels; Verge et al., 1990b) may be explained by an ability of large-caliber NGF-responsive neurons (i.e., those with more branches) to take up and retrogradely transport greater levels of NGF to their neuronal perikarya (Voyvodic, 1989; see also Lasek, 1988). Nevertheless, studies using NGF antiserum provide a means to determine directly which features of the axon reaction (e.g., increased synthesis and axonal transport to tubulin, actin, and GAP-43) are responsive to NGF deprivation.

\section{Summary}

In summary, the present findings are consistent with the hypothesis (Cragg, 1970) that failure to transport retrogradely a neurotrophic factor to the neuronal perikaryon induces the axon reaction. These studies suggest that in sensory neurons NGF is the "trophic" signal whose loss following axotomy leads to the axon reaction. It will be important to identify the factors serving similar "trophic" functions in non-NGF-responsive neurons.

\section{References}

Bernd P, Greene LA (1984) Association of ${ }^{125}$ I-nerve growth factors with $\mathrm{PCl} 2$ pheochromocytoma cells. Evidence for internalization via high-affinity receptors only and for long-term regulation by nerve growth factor of both high- and low-affinity receptors. J Biol Chem 259:15509-15516.

Bondok AA, Sansone FM (1984) Retrograde and transganglionic degeneration of sensory neurons after a peripheral nerve lesion at birth. Exp Neurol 86:322-330.

Cragg BG (1970) What is the signal for chromatolysis? Brain Res 23: $1-21$.

Davies AM, Thoenen H, Barde Y-A (1986) Different factors from the central nervous system and periphery regulate the survival of sensory neurons. Nature 319:497-499.

Davis LG, Dibner MD, Battey JF (1986) Methods in molecular biology, pp 311-314. New York: Elsevier.

Ferri G-L, Sabani A, Abelli L, Polak JM, Dahl D, Portier M-M (1990) Neuronal intermediate filaments in rat dorsal root ganglia: differential distribution of peripherin and neurofilament protein immunoreactivity and effect of capsaicin. Brain Res 515:331-335.

Fitzgerald MP, Wall D, Goedert M, Emson PC (1985) Nerve growth factor counteracts the neurophysiological and neurochemical effects of chronic sciatic nerve section. Brain Res 332:131-141.

Friede RL, Samorajski T (1970) Axon caliber related to neurofilaments and microtubules in sciatic nerve fibers of rats and mice. Anat Rec 167:379-387.

Gillespie MJ, Stein RB (1983) The relationship between axon diameter, myelin thickness and conduction velocity during atrophy of mammalian peripheral nerves. Brain Res 259:41-56.

Gold BG, Dark C (1988a) Somatofugal axonal atrophy produced by colchicine application to the sciatic nerve. Ann Neurol 24:481.

Gold BG, Dark C (1988b) Evidence that the loss of a retrogradely transported muscle-derived factor initiates the axon reaction. Soc Neurosci Abstr 14:255.

Gold BG, Griffin JW, Price DL (1985) Slow axonal transport in acrylamide neuropathy: different abnormalities produced by single-dose and continuous administration. J Neurosci 5:1755-1768.

Gold BG, Griffin JW, Pestronk A, Hoffman PN, Stanley EF, Price DL (1986) Somatofugal axonal atrophy produced by botulinum toxin. Soc Neurosci Abstr 12:1108.

Goldstein ME, Weiss SR, Lazzarini RA, Schneidman PS, Lees JF, Schlaepfer WW (1988) mRNA levels of all three neurofilament proteins decline following nerve transection. Mol Brain Res 3:287292.

Gorin PD, Johnson EM Jr, (1980) Effects of long-term nerve growth factor deprivation on the nervous system of the adult rat: an experimental autoimmune approach. Brain Res 198:27-42.

Green SH, Greene LA (1986) A single $M_{\mathrm{r}}=103,000{ }^{125} \mathrm{I}-\beta$-nerve growth factor affinity-labeled species represents both the low and high affinity forms of the nerve growth factor receptor. J Biol Chem 261: 15316-15326.

Griffin JW, Price DL (1981) Demyelination in experimental $\beta, \beta^{\prime}$ iminodipropionitrile and hexacarbon neuropathies. Lab Invest 45 : 130-141.

Hagg T, Fassholmes B, Vahlsing HL, Manthorpe M, Conner JM, Varon S 
(1989) Nerve growth factor (NGF) reverses axotomy-induced decreases in choline acetyltransferase, NGF receptor and size of medial septum cholinergic axons. Brain Res 505:29-38.

Hamburger V, Brunso-Bechtold JK, Yip JW (1981) Neuronal death in the spinal ganglia of the chick embryo and its reduction by nerve growth factor. J Neurosci 1:60-71.

Heumann R, Korsching S, Bandtlow C, Thoenen H (1987) Changes of nerve growth factor synthesis in non-neuronal cells in response to sciatic nerve transection. I Cell Biol 104:1623-1631.

Hoffman PN, Lasek RJ (1975) The slow component of axonal transport: identification of major structural polypeptides of the axon and their generality among mammalian neurons. J Cell Biol 66:351-366.

Hoffman PN, Lasek RJ (1980) Axonal transport of the cytoskeleton in regenerating motor neurons; constancy and change. Brain Res 202: 317-333.

Hoffman PN, Griffin JW, Price DL (1984) Control of axonal caliber by neurofilament transport. J Cell Biol 99:705-714.

Hoffman PN, Cleveland DW, Griffin JW, Landes PW, Cowen NJ, Price DL (1987) Neurofilament gene expression: a major determinant of axonal caliber. Proc Natl Acad Sci USA 84:3472-3476.

Hohn A, Leibrock J, Bailey K, Barde Y-A (1990) Identification and characterization of a novel member of the nerve growth factor/brainderived neurotrophic factor family. Nature 344:339-341.

Hosang M, Shooter EM (1985) Molecular characteristics of nerve growth factor receptors on PC12 cells. J Biol Chem 260:655-662.

Hulsebosch CE, Perez-Polo JR, Coggeshall RE (1987) In vivo antiNGF induces sprouting of sensory axons in dorsal roots. J Comp Neurol 259:445-451.

Johnson EM Jr, Yip HK (1985) Central nervous system and peripheral nerve growth factor provide trophic support critical to mature sensory neuronal survival. Nature 314:751-752.

Johnson EM, Rich KM, Yip HK (1986) The role of NGF in sensory neurons in vivo. Trends Neurosci 9:33-37.

Kristensson K, Olsson T (1975) Retrograde transport of horseradish peroxidase in transected axons. II. Relationship between rate of transfer from the site of injury to the perikaryon and onset of chromatolysis. J Neurocytology 4:653-661.

Lasek RJ (1988) Studying the intrinsic determinants of neuronal form and function. In: Intrinsic determinants of neuronal form and function (Lasek RJ, Black MM, eds), pp 3-58. New York: Liss.

Leibrock J, Lottspeich F, Hohn A, Hofer M, Hengere B, Masiakowski P, Thoenen H, Barde Y-A (1989) Molecular cloning and expression of brain-derived neurotrophic factor. Nature 341:149-152.

Leonard DGB, Gorham JD, Cole P, Greene LA, Ziff EB (1988) A nerve growth factor-regulated messenger RNA encodes a new intermediate filament protein. J Cell Biol 106:181-193.

Lieberman AR (1971) The axon reaction: a review of the principal features of perikaryal responses to axon injury. Int Rev Neurobiol 14:49-124

Lindsay RM, Harmar AJ (1989) Nerve growth factor regulates expression of neuropeptide genes in adult sensory neurons. Nature 337: 362-364.

Lindsay RM, Shooter, EM, Radeke MJ, Misko TP, Dechant G, Thoenen H, Lindholm D (1990) Nerve growth factor regulates expression of the nerve growth factor receptor gene in adult sensory neurons. Eur J Neurosci 2:389-396.

Longo FM, Vu T-KH, Mobley WC (1990) The in vitro biological effect of nerve growth factor is inhibited by synthetic peptides. Cell Reg 1: 189-195.

Maisonpierre PC, Belluscia L, Squinto S, Ip NY, Furth ME, Lindsay RM, Yancopoulos GD (1990) Neurotrophin-3: a neurotrophic factor related to NGF and BDNF. Science 247:1446-1451.

Matheson SF, Gold BG (1989) Regulation of axonal caliber in adult sensory neurons by nerve growth factor (NGF). J Neuropathol Exp Neurol 48:372

Matheson SF, Gold BG, Mobley WC (1989) Somatofugal axonal atrophy in intact adult sensory neurons following injection of nerve growth factor (NGF) antiserum. Soc Neurosci Abstr 15:707.

Miyata Y, Kashihara Y, Homma S, Kumo M (1986) Effects of nerve growth factor on the survival of synaptic function of Ia sensory neurons axotomized in neonatal rats. J Neurosci 6:2012-2018.

Mobley WC, Rutkowski JL, Tennekoon GI, Gemski J, Buchanan K, Johnston MV (1986) Nerve growth factor increases choline acetyltransferase activity in developing basal forebrain neurons. Mol Brain Res 1:53-62.
Nja A, Purves D (1978) The effects of nerve growth factor and its antiserum on synapses in the superior cervical ganglia of the guinea pig. J Physiol (Lond) 277:53-75.

Oblinger MM, Lasek RJ (1988) Axotomy-induced alterations in the synthesis and transport of neurofilament and microtubules in dorsal root ganglion cells. J Neurosci 8:1747-1758.

Oblinger MM, Wong J, Parysek LM (1989) Axotomy-induced changes in the expression of type III neuronal intermediate filament gene. $J$ Neurosci 9:3766-3775.

Otto D, Unsicker K, Grothe C (1987) Pharmacological effects of nerve growth factor and fibroblast growth factor applied to the transected sciatic nerve on neuron death in adult rat dorsal root ganglia. Neurosci Lett 83:156-160.

Parysek LM, Goldman RD (1988) Characterization of a novel 57 kDa intermediate filament (IF) protein in the nervous system. J Neurosci 8:555-563.

Parysek LM, Chisholm RL, Ley CA, Goldman RD (1988) A type III intermediate filament gene is expressed in mature neurons. Neuron 1:395-401.

Pfeiffer G, Friede RL (1985) A morphometric study of nerve fiber atrophy in rat spinal roots. J Neuropathol Exp Neurol 44:546-558.

Portier M-M, de Nechaud B, Gros F (1984) Peripherin, a new member of the intermediate filament protein family. Dev Neurosci 6:335-344.

Price DL, Griffin JW, Hoffman PN, Cork LC, Spencer PS (1984) The response of motor neurons to injury and disease. In: Peripheral neuropathy, Vol 1 (Dyck PJ, Thomas PK, Lambert EH, Bunge R, eds), pp 732-759. Philadelphia: Saunders.

Purves D (1988) Body and brain: a trophic theory of neural connections. Cambridge MA: IIarvard UP.

Raivich G, Kreutzberg GW (1987) Expression of growth factor receptors in injured nervous tissue. I. Axotomy leads to a shift in the cellular distribution of specific $\beta$-nerve growth factor binding in the injured and regenerating PNS. J Neurocytol 16:261-268.

Rich KM, Yip HK, Osborne PA, Schmidt RE, Johnson EM Jr (1984) Role of nerve growth factor in the adult dorsal root ganglia neurons and its response to injury. J Comp Neurol 230:110-118.

Rich KM, Luszczinski JR, Osborne PA, Johnson EM Jr (1987) Nerve growth factor protects adult sensory neurons from cell death and atrophy caused by nerve injury. J Neurocytol 16:261-268.

Richardson PM, Riopelle RJ (1984) Uptake of nerve growth factor along peripheral and spinal axons of primary sensory neurons. J Neurosci 4:1683-1689.

Richardson PM, Verge Issa VMK, Riopelle RJ (1986) Distribution of neuronal receptors for nerve growth factor in the rat. $J$ Neurosci 6:2312-2321.

Schwartz JP, Pearson J, Johnson EM Jr (1982) Effect of exposure to anti-NGF on sensory neurons of adult rats and guinea pigs. Brain Res 244:378-381.

Sofroniew MV, Galletly NP, Isacson O, Svendsen CN (1990) Survival of adult basal forebrain cholinergic neurons after loss of target neurons. Science 247:338-342.

Spencer PS, Schaumburg HH (1977) Ultrastructural studies of the dying-back process: III. The evolution of experimental peripheral giant axonal degeneration. J Neuropathol Exp Neurol 36:276-299.

Stockel K, Schwab M, Thoenen H (1975) Specificity of retrograde transport of nerve growth factor (NGF) in sensory neurons: a biochemical and morphological study. Brain Res 89:1-14.

Suh YS, Kyungsoon C, Coggeshall RE (1984) A study of axonal diameters and axonal lumbosacral roots and nerves in the rat. $J$ Comp Neurol 222:473-481.

Sutter A, Riopelle RJ, Harris-Warrick RM, Shooter EM (1979) Nerve growth factor receptors. J Biol Chem 254:5972-5982.

Taniuchi M, Schweitzer JB, Johnson EM Jr (1986a) Nerve growth factor receptor molecules in rat brain. Proc Natl Acad Sci USA 83: 1950-1954.

Taniuchi M, Clark HB, Johnson EM Jr (1986b) Induction of nerve growth factor receptor in Schwann cells after axotomy. Proc Natl Acad Sci USA 83:4054-4098.

Taniuchi M, Clark HB, Schweitzer JB, Johnson EM Jr (1988) Expression of nerve growth factor receptors by Schwann cells of axotomized peripheral nerves: ultrastructural location, suppression by axonal contact, and binding properties. J Neurosci 8:664-681.

Tetzlaff W, Bisby MA, Kreutzberg GW (1988) Changes in cytoskeletal proteins in the rat facial nucleus following axotomy. $J$ Neurosci 8 : 3181-3189. 
Thoenen II, Barde Y-A (1980) Physiology of nerve growth factor. Physiol Rev 60:1284-1335.

Urschel BA, Hulsebosch CE (1990) Schwann cell-neuronal interactions in the rat involve nerve growth factor. J Comp Neurol 296:114122.

Verge VMK, Riopelle RJ, Richardson PM (1989a) Nerve growth factor receptors on normal and injured sensory neurons. J Neurosci 9 . 914-922.

Verge VMK, Richardson PM, Benoit R, Riopelle RJ (1989b) Histochemical characterization of sensory neurons with high-affinity receptors for nerve growth factor. J Neurocytol 18:583-591.

Verge VMK, Tetzlaff W, Richardson PM, Bisby MA (1990a) Correlation between GAP43 and nerve growth factor receptors in rat sensory neurons. J Neurosci 10:926-934.

Verge VMK, Tetzlaff W, Richardson PM, Bisby MA (1990a) Cor- of nerve growth factor on neurofilament gene expression in mature primary sensory neurons. J Neurosci 10:2018-2025.

Voyvodic JT (1989) Target size regulates calibre and myelination of sympathetic axons. Nature 342:430-433.

Wong J, Oblinger MM (1987) Changes in neurofilament gene expression occur after axotomy of dorsal root ganglion neurons: an in situ hybridization study. Metab Brain Dis 2:291-303.

Yan Q, Johnson EM Jr (1988) An immunohistochemical study of the nerve growth factor receptor in developing rats. J Neurosci 8:34813498.

Yip HK, Rich KM, Lampe PA, Johnson EM Jr (1984) The effects of nerve growth factor and its antiserum on the postnatal development and survival after injury of sensory neurons in rat dorsal root ganglia. J Neurosci 4:2986-2992. 